\title{
High-flow nasal cannula oxygen therapy is superior to conventional oxygen therapy but not to noninvasive mechanical ventilation on intubation rate: a systematic review and meta-analysis
}

\author{
Huiying Zhao ${ }^{1 *+}$, Huixia Wang ${ }^{1+}$, Feng Sun ${ }^{2}$, Shan Lyu ${ }^{1}$ and Youzhong An ${ }^{1 *}$
}

\begin{abstract}
Background: High-flow nasal cannula oxygen (HFNC) is a relatively new therapy used in adults with respiratory failure. Whether it is superior to conventional oxygen therapy (COT) or to noninvasive mechanical ventilation (NIV) remains unclear. The aim of the present study was to investigate whether HFNC was superior to either COT or NIV in adult acute respiratory failure patients.
\end{abstract}

Methods: A review of the literature was conducted from the electronic databases from inception up to 20 October 2016. Only randomized clinical trials comparing HFNC with COT or HFNC with NIV were included. The intubation rate was the primary outcome; secondary outcomes included the mechanical ventilation rate, the rate of escalation of respiratory support and mortality.

Results: Eleven studies that enrolled 3459 patients (HFNC, $n=1681)$ were included. There were eight studies comparing HFNC with COT, two comparing HFNC with NIV, and one comparing all three. HFNC was associated with a significant reduction in intubation rate $(\mathrm{OR} 0.52,95 \% \mathrm{Cl} 0.34$ to $0.79, P=0.002)$, mechanical ventilation rate (OR $0.56,95 \% \mathrm{Cl} 0.33$ to $0.97, P=0.04$ ) and the rate of escalation of respiratory support (OR $0.45,95 \% \mathrm{Cl} 0.31$ to 0.67 , $P<0.0001)$ when compared to COT. There was no difference in mortality between HFNC and COT utilization (OR $1.01,95 \% \mathrm{Cl} 0.67$ to $1.53, P=0.96)$. When HFNC was compared to NIV, there was no difference in the intubation rate (OR $0.96 ; 95 \% \mathrm{Cl} 0.66$ to $1.39, P=0.84$ ), the rate of escalation of respiratory support (OR 1.00 , $95 \% \mathrm{Cl} 0.77$ to $1.28, P=0.97$ ) or mortality (OR $0.85,95 \% \mathrm{Cl} 0.43$ to $1.68, P=0.65$ ).

Conclusions: Compared to COT, HFNC reduced the rate of intubation, mechanical ventilation and the escalation of respiratory support. When compared to NIV, HFNC showed no better outcomes. Large-scale randomized controlled trials are necessary to prove our findings.

Trial registration: PROSPERO International prospective register of systematic reviews on May 25, 2016 registration no. CRD42016039581.

Keywords: High-flow nasal cannula oxygen (HFNC), Conventional oxygen therapy (COT), Noninvasive mechanical ventilation (NIV), Intubation, Mortality

\footnotetext{
* Correspondence: zhaohuiying109@sina.com; youzhonganicu@163.com

${ }^{\dagger}$ Equal contributors

'Department of Critical Care Medicine, Peking University People's Hospital,

No. 11 Xizhimen South Street, Xicheng District, Beijing 100044, China

Full list of author information is available at the end of the article
} 


\section{Background}

High-flow nasal cannula oxygen (HFNC) is a relatively new and increasingly used therapy in adults with acute respiratory failure [1]. HFNC can deliver heated humidified oxygen through nasal prongs and provide much higher and more predictable rates of gas flow (maximum flow of $60 \mathrm{~L} / \mathrm{min})$ and fraction of inspired oxygen $\left(\mathrm{FiO}_{2}\right)$ (up to 1.0) [2-4].

HFNC has several advantages when compared to conventional oxygen therapy (COT): (1) the high-flow rates match the patient's inspiratory flow rates, which creates a positive pressure effect $[5,6]$ and reduces the anatomic dead space [7]; (2) HFNC can deliver a predictable and constant $\mathrm{FiO}_{2}$ [8]; (3) HFNC can increase the partial arterial pressure of oxygen $\left(\mathrm{PaO}_{2}\right) / \mathrm{FIO}_{2}$ ratio, which reduces the entrainment of room air and the dilution of oxygen [1, 2]; (4) the heated and humidified gas that is inhaled can improve mucociliary motion and sputum clearance [3, 9]; and (5) there is reduced upper airway resistance, reduced work of breathing [10] and improvement in thoraco-abdominal synchrony [11, 12]. Based on the above advantages, several studies found that HFNC could improve comfort level [13-15], increase oxygenation [12, 14-17] and decrease the dyspnoea score in adult patients $[3,12,14,17]$. Nevertheless, there has been no clear consensus on treatment outcomes (such as intubation rate, escalated respiratory support rate and mortality) $[13,18-22]$.

Compared to HFNC, noninvasive mechanical ventilation (NIV) can create a much higher gas flow rate and positive airway pressure but is not comfortable and has many complications [23, 24]. Recently, well-designed randomized controlled trials (RCTs) have not differentiated the effect of HFNC and NIV on intubation rates and mortality [18, 25]. To decrease complexity, a recently published meta-analysis showed no significant difference in mortality or intubation rates when HFNC was compared to COT and NIV [26]. The conclusion of this study might be misleading: first, COT and NIV are very different in terms of the mechanism of action and clinical application; second, the combination of COT and NIV not only increased patient heterogeneity but also increased the power of statistical bias. A separate comparison of HFNC with COT and NIV should result in more reasonable conclusions. Maitra et al. included only six RCTs in their meta-analysis that compared only the prognosis of higher respiratory support, and found no significant difference between HFNC and either standard oxygen therapy or NIV [27]. The small number of studies included in the meta-analysis makes its application limited.

Therefore, we conducted a meta-analysis to investigate the effect of HFNC on the rates of intubation, mechanical ventilation, the escalation of respiratory support and its effect on mortality versus COT or NIV in adult patients with respiratory failure.

\section{Methods}

We conducted a systematic review in accordance with the methods recommended in the Preferred Reporting Items for Systematic Reviews and Meta-Analyses (PRISMA) guidelines [28].

\section{Search strategy}

Using electronic and manual searching, a literature review was performed from the electronic databases inception up to 20 October 2016 in the Cochrane Library, Embase and Ovid Medline without language restrictions. The following search terms were used: 'hfnc', 'hfnp', 'hhfnox,' 'hfno', '(high flow) adj5 nasal', '(high flow) adj5 oxygen,' 'high-flow adj5 nasal' and 'nasal adj5 (high flow)'. The search strategy is in the Appendix (Additional file 1). In addition, we manually searched clinical trials.gov and the bibliographies of randomized controlled trials, meta-analyses, and systematic reviews to identify other potentially relevant studies. The references of all included articles were also checked manually to identify additional eligible studies. The literature review was conducted independently by two authors (HYZ and HXW). Disparities in the literature review were resolved by a consensus of all authors.

\section{Inclusion and exclusion criteria}

The following criteria were used for inclusion in our meta-analysis:

1. Type of study: randomized controlled trials;

2. Population: adult patients with respiratory failure who received oxygen therapy;

3. Intervention: HFNC treatment compared either COT or NIV;

4. Predefined outcomes: intubation, mechanical ventilation (includes noninvasive mechanical ventilation and invasive mechanical ventilation), escalation of respiratory support (HFNC, NIV or intubation) and mortality.

If there was more than one eligible trial from one team, the study with the most recent publication date was used in the analysis.

Exclusion criteria: the types of articles excluded from the analysis were reviews, retrospective studies, observational studies, case reports, animal studies, studies conducted on children, studies examining only psychological mechanisms, unrelated studies (e.g., HFNC not used in patients), duplicate reports, studies involving repeated experiments (commentary articles on specific studies or secondary analyses of experimental data), studies not in 
either the English or the Chinese language and nonrandomized trials.

The primary outcome of our study was to investigate whether HFNC versus COT or HFNC versus NIV resulted in a similar intubation rate. The secondary outcomes were whether HFNC versus COT had similar rates of mechanical ventilation and rates of escalation of respiratory support and mortality, and whether HFNC versus NIV had similar rates of escalation of respiratory support and mortality.

\section{Data extraction}

Two reviewers (HYZ and HXW) extracted the data independently using a predefined data extraction form. Disagreements were resolved through discussion or consensus with a third reviewer (FS). The data extracted included the study ID (together with the first author's name and publication year), country, study design, setting, control therapy, duration of therapy, primary and secondary outcomes and clinical outcomes. We also checked the supplementary files and contacted the authors for more detailed information if necessary.

\section{Quality assessment and publication bias}

Two independent reviewers assessed the methodological quality of the included trials using the Cochrane Collaboration Risk of Bias tool [29] within the RevMan5.3 software, which considers seven different domains: adequacy of sequence generation; allocation sequence concealment; blinding of participants and caregivers; blinding for outcome assessment; incomplete outcome data; selective outcome reporting; and the presence of other potential sources of bias not accounted for in the other six domains (the current research primarily refers to receiver sponsorship or oxygen therapy devices from Fisher and Paykel Healthcare or from other organizations). Based on the method of the trials, each was graded as "yes", "no" or "unclear", to reflect a high, low risk or uncertain risk of bias, respectively. Two reviewers (HYZ and HXW) made judgments independently. In cases of disagreement, resolution was first attempted by discussion and then by consulting a third author (FS) for arbitration.

Funnel plots were used to assess the possibility of publication bias and were implemented in RevMan 5.3 software. The Egger regression test was used to measure funnel plot asymmetry [30] and was implemented using Stata 12.0 (StataCorp LP, TX, USA).

\section{Grading the quality of the evidence}

We used the methodology of the Grades of Recommendation, Assessment, Development and Evaluation (GRADE) Working Group to assess the overall quality of the evidence for the primary and secondary outcomes in the following domains: risk of bias, inconsistency, indirection, imprecision and publication bias. These were classified as very low, low, medium and high [31].

\section{Statistical analysis}

Statistical analyses were performed using RevMan 5.3 software (Cochrane Library, London, UK). We combined data from all trials to estimate the pooled odds ratio (OR) with 95\% confidence intervals (CIs) for the rates of intubation, mechanical ventilation, escalation of respiratory support and mortality. Pooled ORs with 95\% CI were estimated by the Mantel-Haenszel method. ORs were undefined and excluded for studies with no event in either arm. The analysis was performed using a random effects model. Heterogeneity was tested using a weighted Mantel-Haenszel $\chi^{2}$ test and was quantified using the $I^{2}$ statistic as implemented in RevMan $I^{2}$ values, which describes the percentage of the variability in effect and computes estimates that are due to heterogeneity rather than sampling error. $I^{2}$ values of $25-50 \%$ indicated low, $50-75 \%$ indicated moderate, and $>75 \%$ indicated high heterogeneity. A value $>50 \%$ may be considered substantial heterogeneity [32]. A $P$ value of 0.1 was used to denote the statistical significance of heterogeneity. Differences between subgroups were analysed using the test of subgroup differences described by Deeks et al., and the results were expressed using the $P$ values. $P<0.05$ was considered statistically significant.

\section{Subgroup analysis}

We utilized subgroup analysis to assess possible influences of the oxygen therapy system on clinical outcomes, which allowed us to explore the possible causes of the heterogeneity. In the comparison of HFNC to $\mathrm{COT}$, we first explored whether there was a different treatment effect of the oxygen therapy system in patients with post-extubation acute respiration failure (ARF) and patients with ARF that occurred for other reasons. Second, we assessed the effect of trials that allowed COT to escalate to HFNC versus those studies that did not. Moreover, we also compared the results of RCTs with patients from single-centre studies versus patients from multi-centre studies.

\section{Results}

\section{Study identification and selection}

The initial search of the database revealed 754 articles, and other sources revealed 24 articles. After the removal of duplicates, there were 601 articles that were screened based on their titles and abstracts to identify potentially eligible trials. The full texts of 26 articles were assessed, and 15 studies available in full text were excluded: 8 were not RCTs [10, 15, 16, 33-37]; 1 was not in the English or Chinese language [38]; 4 did not include the outcomes of our meta-analysis [39-42]; and 1 applied 
HFNC for bronchoscopy but not for treatment [43] (Additional file 2). In total, 10 RCTs (11 studies, 1 study compared all three groups) [13, 18-22, 25, 44-47] were eligible and were included in this meta-analysis, which ultimately included 3459 subjects. A PRISMA flow diagram of the selection of studies is shown in Fig. 1.

The characteristics of individual studies included in this meta-analysis are presented in Table 1. There was one trial published over two articles: HFNC versus COT [19] and HFNC versus NIV [25]. Eight studies [13, 19-22, 44-46] compared HFNC with COT, and two studies [25, 47] compared HFNC with NIV, whereas another study [18] compared HFNC with both. Two studies $[13,20]$ were conducted in emergency departments (EDs), and others were conducted in intensive care units (ICUs). Eight were multi-centre studies. There were two studies performed in Australia [13, 44], three in France [18, 45, 47], three in New Zealand [20, $22,46]$, two in Spain $[19,25]$ and one in Italy [21].

For all RCTs in this meta-analysis, most of the domains were evaluated as having low risk of bias (allocation sequence concealment, blinding for outcome assessment, incomplete outcome data and selective outcome reporting of domains). Most notably, blinding of participants and personnel was not possible in these trials because of the dramatic differences between HFNC, COT and NIV; therefore, performance bias was considered to be a high risk in all the studies. Other types of bias are herein referred to as commercial interference. Seven of the articles $[13,18-20,44-46]$ stated that the trial design and data analysis was independent of commercial interference; nevertheless, another three studies [21, 22, 47] did not make this clarification. In addition, randomization of sequence generation was unclear in two studies $[45,47]$ because they did not describe the specific methods of randomization. The risk of summary bias in individual studies is shown in Fig. 2, Fig. 3 and Additional file 3.

Funnel plots were visually inspected and did not demonstrate evidence of publication bias (Fig. 4) The Egger regression test showed that the tests of asymmetry were not significant for any of the endpoints, including intubation rate for HFNC versus COT (OR $-0.48,95 \%$ CI $-2.45,1.65, P=0.65$ ); HFNC versus NIV (OR $0.27,95 \%$ $\mathrm{CI}-331.57,345.82, P=0.83)$, and for secondary outcomes, HFNC versus COT for mechanical ventilation rate $(\mathrm{OR}-0.56,95 \% \mathrm{CI}-2.80,1.72, P=0.59)$, escalation

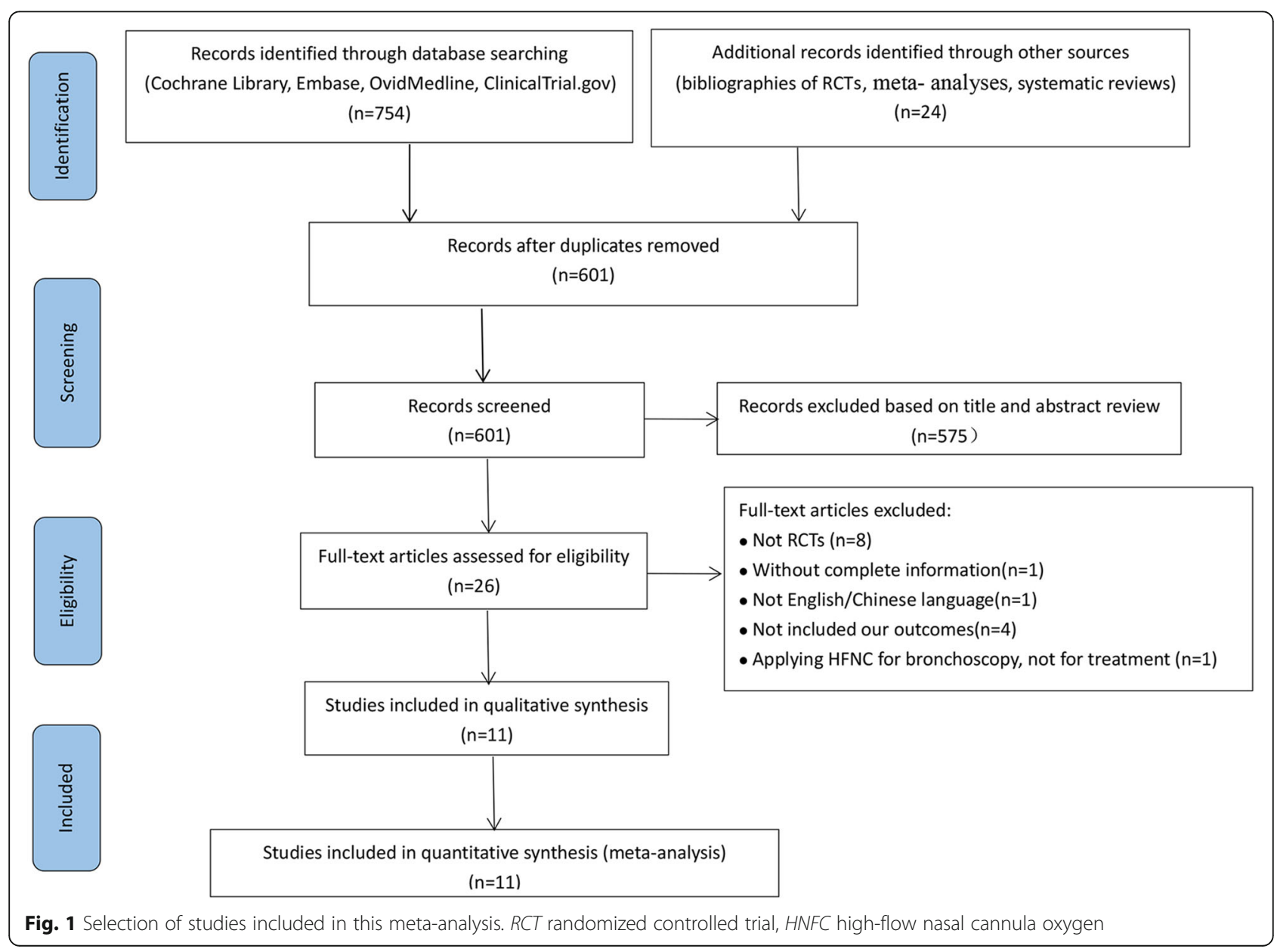


Table 1 Main characteristics of the 11 studies included in the meta-analysis

\begin{tabular}{|c|c|c|c|c|c|c|c|c|c|c|}
\hline \multirow[t]{2}{*}{ Study } & \multirow[t]{2}{*}{ Country } & \multirow[t]{2}{*}{ Setting } & \multirow[t]{2}{*}{$\begin{array}{l}\text { Study } \\
\text { design }\end{array}$} & \multirow[t]{2}{*}{ Patients } & \multirow[t]{2}{*}{ Control } & \multirow[t]{2}{*}{$\begin{array}{l}\text { Duration } \\
\text { (h) }\end{array}$} & \multirow{2}{*}{$\begin{array}{l}\text { Primary } \\
\text { outcomes } \\
\text { Intubation }\end{array}$} & \multicolumn{3}{|l|}{$\begin{array}{l}\text { Secondary } \\
\text { outcomes }\end{array}$} \\
\hline & & & & & & & & $\begin{array}{l}\text { Mechanical } \\
\text { ventilation }\end{array}$ & Escalation & Mortality \\
\hline Bell N, 2015 [13] & Australia & $\mathrm{ED}$ & $\begin{array}{l}\text { Multi- } \\
\text { centre }\end{array}$ & $\begin{array}{l}\text { Acute undifferentiated } \\
\text { shortness of breath }\end{array}$ & $\begin{array}{l}\text { FM/nasal } \\
\text { prongs }\end{array}$ & $2 \mathrm{~h}$ & Yes & Yes & Yes & No \\
\hline $\begin{array}{l}\text { Corley A, 2015 } \\
{[44]}\end{array}$ & Australia & $\mathrm{ICU}$ & $\begin{array}{l}\text { Multi- } \\
\text { centre }\end{array}$ & $\begin{array}{l}\text { Post-extubation after } \\
\text { cardiac surgery with } \\
\mathrm{BMI} \geq 30 \mathrm{~kg} / \mathrm{m}^{2}\end{array}$ & $\begin{array}{l}\text { FM/nasal } \\
\text { cannula }\end{array}$ & $24 \mathrm{~h}$ & Yes & Yes & Yes & No \\
\hline Frat JP, 2015 [18] & France & ICU & $\begin{array}{l}\text { Multi- } \\
\text { centre }\end{array}$ & $\begin{array}{l}\text { AHRF (without } \\
\text { hypercapnia) }\end{array}$ & FM/NIV & $48 \mathrm{~h}$ & Yes/yes & Yes/- & Yes/yes & Yes/yes \\
\hline $\begin{array}{l}\text { Hernandez } \mathrm{G}^{1} \text {, } \\
2016[19]\end{array}$ & Spain & $\mathrm{ICU}$ & $\begin{array}{l}\text { Multi- } \\
\text { centre }\end{array}$ & $\begin{array}{l}\text { Post-extubation RF in } \\
\text { low risk for reintubation }\end{array}$ & $\begin{array}{l}\text { FM/nasal } \\
\text { cannula }\end{array}$ & $24 \mathrm{~h}$ & Yes & Yes & Yes & Yes \\
\hline $\begin{array}{l}\text { Jones PG, } 2015 \\
\text { [20] }\end{array}$ & $\begin{array}{l}\text { New } \\
\text { Zealand }\end{array}$ & $E D$ & $\begin{array}{l}\text { Single- } \\
\text { centre }\end{array}$ & Hypoxia and tachypnea & $\begin{array}{l}\mathrm{FM} / \text { nasal } \\
\text { prongs }\end{array}$ & $3 \mathrm{~h}$ & Yes & Yes & Yes & Yes \\
\hline \multicolumn{11}{|l|}{$\begin{array}{l}\text { Lemiale V, } 2015 \\
\text { [45] }\end{array}$} \\
\hline & France & ICU & $\begin{array}{l}\text { Multi- } \\
\text { centre }\end{array}$ & $\begin{array}{l}\text { Immunocompromised } \\
\text { patients with AHRF }\end{array}$ & FM & $2 \mathrm{~h}$ & Yes & Yes & Yes & No \\
\hline $\begin{array}{l}\text { Maggiore SM, } 2014 \\
{[21]}\end{array}$ & Italy & $\mathrm{ICU}$ & $\begin{array}{l}\text { Multi- } \\
\text { centre }\end{array}$ & Post-extubation ARF & FM & $48 \mathrm{~h}$ & Yes & Yes & Yes & Yes \\
\hline Parke R, 2013 [22] & $\begin{array}{l}\text { New } \\
\text { Zealand }\end{array}$ & CVICU & $\begin{array}{l}\text { Single- } \\
\text { centre }\end{array}$ & $\begin{array}{l}\text { Post-extubation after } \\
\text { cardiac surgery }\end{array}$ & $\begin{array}{l}\text { FM/or nasal } \\
\text { prongs }\end{array}$ & $24 \mathrm{~h}$ & Yes & Yes & Yes & Yes \\
\hline Parke R, 2011 [46] & $\begin{array}{l}\text { New } \\
\text { Zealand }\end{array}$ & CVICU & $\begin{array}{l}\text { Single- } \\
\text { centre }\end{array}$ & Mild to moderate AHRF & FM & $24 \mathrm{~h}$ & - & Yes & Yes & No \\
\hline $\begin{array}{l}\text { Stephan F, } 2015 \\
{[47]}\end{array}$ & France & $\begin{array}{l}\text { CTVS } \\
\mathrm{ICU}\end{array}$ & $\begin{array}{l}\text { Multi- } \\
\text { centre }\end{array}$ & $\begin{array}{l}\text { ARF after cardiothoracic } \\
\text { surgery }\end{array}$ & NIV & $\begin{array}{l}\text { Period of } \\
\text { ICU stay }\end{array}$ & Yes & - & Yes & Yes \\
\hline $\begin{array}{l}\text { Hernandez } \mathrm{G}^{2}, \\
2016[25]\end{array}$ & Spain & $\mathrm{ICU}$ & $\begin{array}{l}\text { Multi- } \\
\text { centre }\end{array}$ & $\begin{array}{l}\text { Post-extubation } \mathrm{RF} \text { in } \\
\text { high risk for reintubation }\end{array}$ & NIV & $24 \mathrm{~h}$ & Yes & - & Yes & Yes \\
\hline
\end{tabular}

CTVS cardiothoracic and vascular surgery, ICU intensive care units, CVICU cardiothoracic and vascular ICU, COT conventional oxygen therapy, NIV noninvasive mechanical ventilation, $E D$ emergency department, $B M I$ body mass index, $A H R F$ acute hypoxaemic respiratory failure, $R F$ respiratory failure, $F M$ face mask an these studies, the group of patients who received COT could be escalated to HFNC if necessary, whereas the other patients were not escalated to HFNC Hernandez $G^{1}$ [19] 2016 and Hernandez $G^{2}$ [25] 2016 were two articles from the same trial

rate $(\mathrm{OR}-1.73,95 \% \mathrm{CI}-3.35,0.52, P=0.13)$, and mortality rate $(\mathrm{OR}-0.28,95 \% \mathrm{CI}-3.17,2.65, P=0.80)$; HFNC versus COT for escalation rate (OR 0.60, 95\% CI $-125.28,137.65, P=0.66$ ), and mortality rate (OR -0.75 , 95\% CI -203.51, 180.89, $P=0.80$ ) (Additional file 4).

The GRADE quality evidence was assessed within GRADEpro software, and the results were as follows: for comparison of HFNC with COT, the quality of evidence on intubation rate and escalation rate was thought to be moderate, whereas evidence on the mechanical ventilation rate and mortality was thought to be low. The common reason for the demotion of RCTs was mainly a lack of blinding. For the rate of mechanical ventilation, the other reason was inconsistency, and for mortality, it was imprecision.

On assessment of the GRADE quality evidence of studies that compared HFNC with NIV, the quality of evidence on the intubation rate and mortality was thought to be very low, mainly because of the lack of blinding, inconsistency and imprecision. The quality of evidence on the escalation rate was thought to be low, and the main reason was a lack of blinding and imprecision. The summary of the findings and the quality of the analysis is provided in Table 2 and Table 3.

\section{Primary outcomes}

Compared to COT, HFNC was associated with a significant reduction in the intubation rate (OR 0.52, 95\% CI 0.34 to $0.79, P=0.002$; $\mathrm{M}-\mathrm{H}$ random; $n=1854$; heterogeneity $I^{2}=9 \%, P=0.36$ ) (Fig. 5a).

No difference was found in the intubation rates between HFNC and NIV therapy (OR 0.96, 95\% CI 0.66 to $1.39, P=0.84 ; \mathrm{M}-\mathrm{H}$ random; $n=1651$; heterogeneity $I^{2}=53 \%, P=0.12$ ) (Fig. 5b).

\section{Secondary outcomes}

Nine RCTs that recruited 1914 patients showed that the use of HFNC significantly reduced the mechanical ventilation rate (OR $0.56,95 \%$ CI 0.33 to $0.97, P=0.04$ ), and the heterogeneity was moderate with $I^{2}=60 \%$ for heterogeneity ( $P=0.01, \mathrm{M}-\mathrm{H}$ random) (Fig. 6a). 


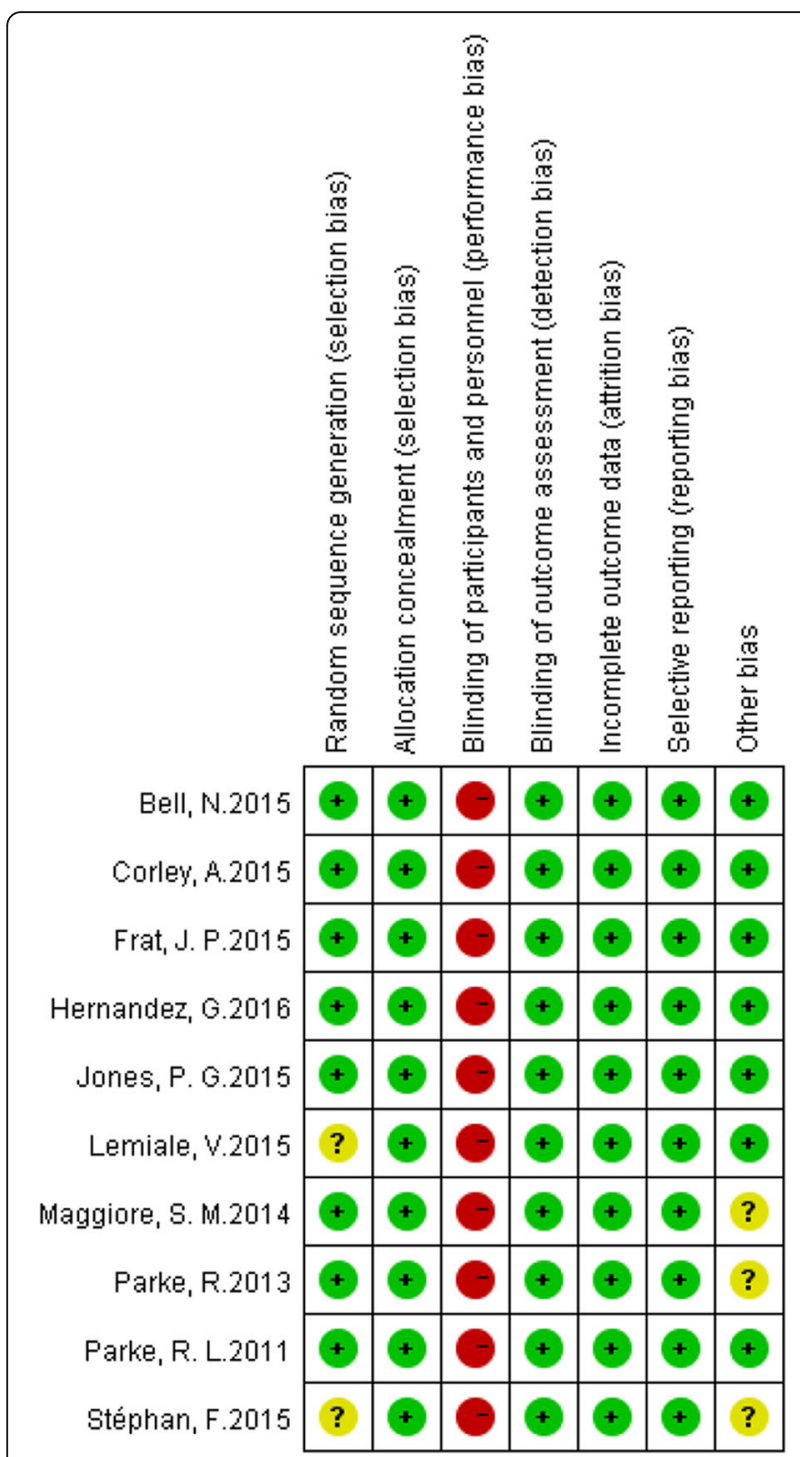

Fig. 2 Methodological quality of trials using the Cochrane risk of bias tool. Symbols show low risk of bias (+), unclear risk of bias (?) or high risk of bias (-)
The overall rate of escalation of respiratory support was also significantly lower in the HFNC group when compared with the COT group (OR 0.45, 95\% CI 0.31 to $0.67, P<0.00001$ ), and the heterogeneity was low with $I^{2}=34 \%$ for heterogeneity $(P=0.15, \mathrm{M}-\mathrm{H}$ random $)$ (Fig. 6b). Only five RCTs [18-22] expressed data on mortality, and there was no difference between HFNC and COT therapies (OR 1.01, 95\% CI 0.67 to $1.53, P=0.96$; $\mathrm{M}-\mathrm{H}$ random; $n=1497$; heterogeneity $\left.I^{2}=0 \%, P=0.52\right)$ (Fig. 6c).

Three RCTs that included 1651 patients compared HFNC with NIV. There was no significant difference in the rate of escalation of respiratory support (OR 1.00, 95\% CI 0.77 to $1.28, P=0.97$; $\mathrm{M}-\mathrm{H}$ random; heterogeneity $I^{2}=17 \%, P=0.30$ ) (Fig. 7a) or in mortality (OR 0.85 , 95\% CI 0.43 to $1.68, P=0.65$; $\mathrm{M}-\mathrm{H}$ random; heterogeneity $I^{2}=69 \%, P=0.04$ ) (Fig. 7b).

\section{Subgroup analysis of HFNC versus COT Reasons for ARF}

Subgroup analysis showed that four trials included patients with post-extubation ARF [19, 21, 22, 44] and were associated with a significant reduction in the intubation rate (OR $0.37,95 \% \mathrm{CI} 0.20$ to $0.70, P=0.002 ; \mathrm{M}-\mathrm{H}$ random; $n=1128$; heterogeneity $I^{2}=10 \%, P=0.34$ ). However, the other four trials included patients with AFR due to other reasons [13, 18, 20,45], and there was no significant effect on the intubation rate (OR 0.72 , 95\% CI 0.44 to $1.19, P=0.20$; M-H random; $n=726$; heterogeneity $I^{2}=0 \%, P=0.73$ ).

\section{Escalation stage}

In the subgroup analysis, a significant reduction was also observed (OR 0.51, 95\% CI 0.32 to $0.81, P=0.004 ; \mathrm{M}-\mathrm{H}$ random; $n=1258$; heterogeneity $I^{2}=21 \%, P=0.28$ ) when COT was not allowed to progress to HFNC [18-21, 45]. However, no difference was observed (OR 0.70, 95\% CI 0.09 to $5.37, \quad P=0.73 ; \quad \mathrm{M}-\mathrm{H}$ random; $n=596$;

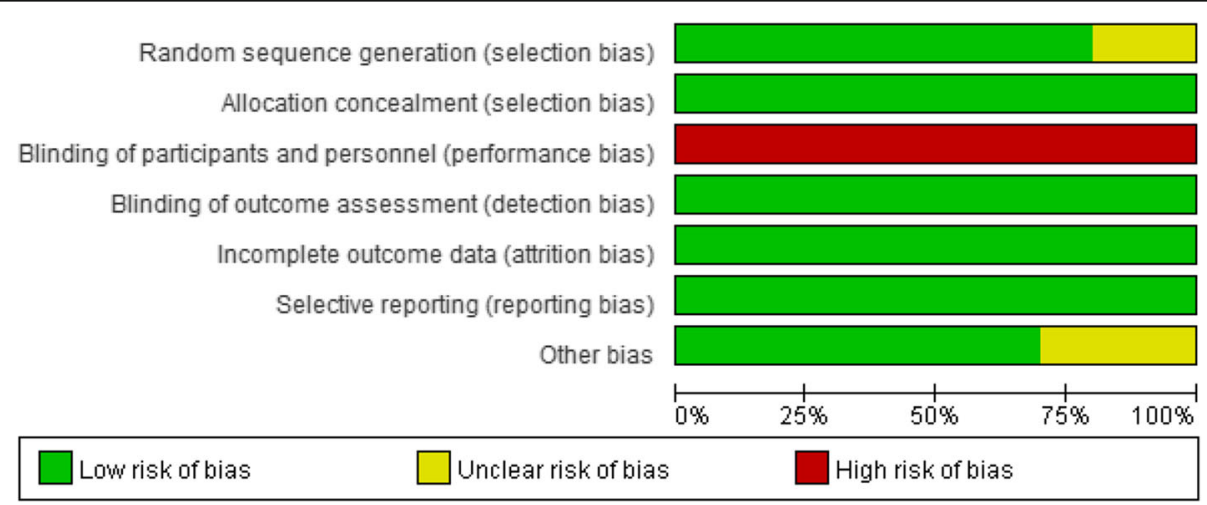

Fig. 3 Overall risk of bias using the Cochrane risk of bias tool 


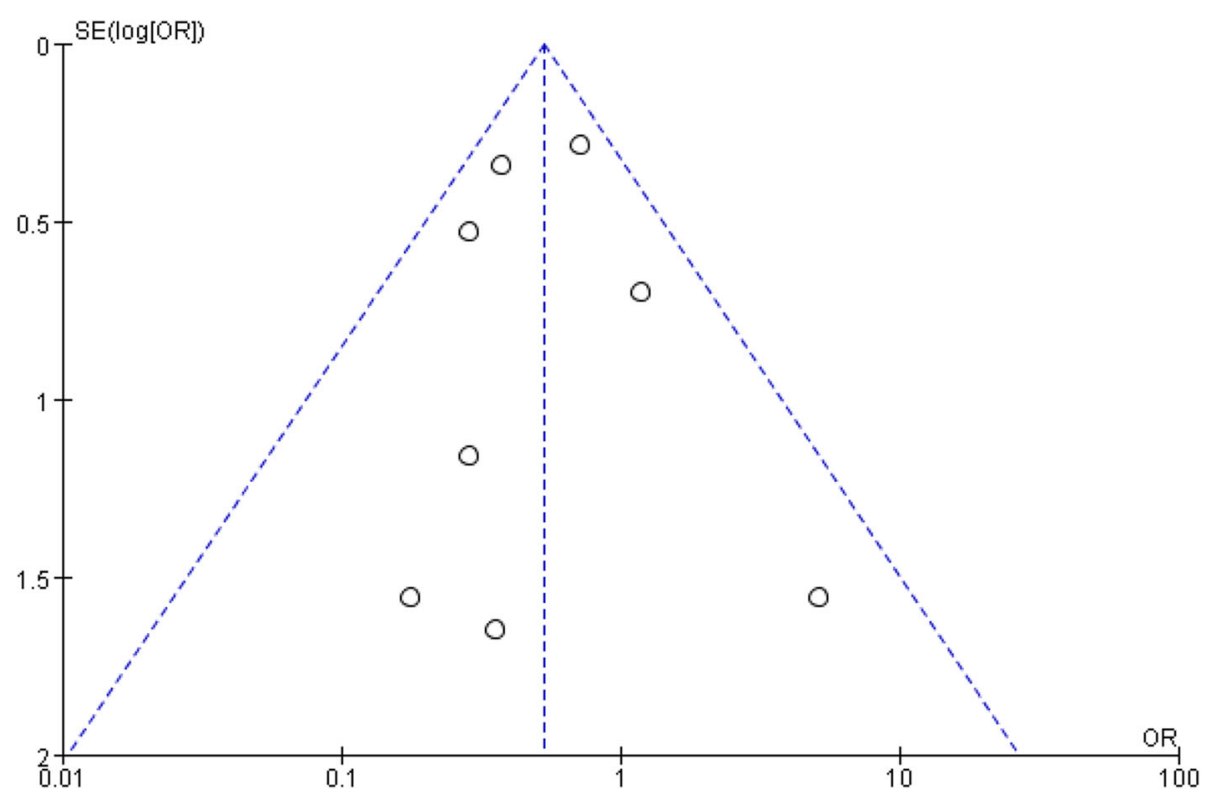

Fig. 4 Funnel plot comparing of the intubation rate between high-flow nasal cannula oxygen (HFNC) and conventional oxygen therapy (COT) by Log odds ratio. OR odd ratio, SE standard error

heterogeneity $\left.I^{2}=23 \%, P=0.27\right)$ when COT was allowed to progress to HFNC $[13,22,44]$.

\section{Type of study design}

In the subgroup analyses of the two single-centre trials [20, 22], there was no effect on the intubation rate (OR 1.01, 95\% CI 0.06 to $16.73, P=1.00$; $\mathrm{M}-\mathrm{H}$ random; $n=663$; heterogeneity $I^{2}=55 \%, P=0.14$ ). However, in six multi-centre trials $[13,18,19,21,44,45]$, there was a significant reduction in the incidence of intubation (OR $0.51,95 \%$ CI 0.34 to $0.77, P=0.001$; M-H random; $n=1191$; heterogeneity $I^{2}=$ $6 \%, P=0.38)$. The primary and secondary outcomes of the subgroup analysis are shown in Additional file 5.

\section{Discussion}

The main finding of our study was that HFNC significantly reduced the rate of intubation, mechanical ventilation and escalation of respiratory support compared with COT in adult patients with respiratory failure, but there was no difference in mortality. On the other hand, when compared to NIV, no significant difference in intubation rate, escalation of respiratory support rate or mortality was detected.

Our results were partially different from two recent meta-analyses of HFNC in adult patients [26, 27]. Our meta-analysis was registered on the PROSPERO website before the other authors published, and we included

Table 2 Quality of evidence of the studies that compared HFNC to COT that were included in the meta-analysis, according to Grades of Recommendation, Assessment, Development and Evaluation (GRADE)

\begin{tabular}{|c|c|c|c|c|c|c|c|c|c|c|}
\hline \multirow[t]{2}{*}{ Outcomes } & \multicolumn{2}{|c|}{$\begin{array}{l}\text { Anticipated absolute } \\
\text { effects }(95 \% \mathrm{Cl})\end{array}$} & \multirow{2}{*}{$\begin{array}{l}\text { Relative } \\
\text { effect OR, } \\
(95 \% \mathrm{Cl})\end{array}$} & \multirow[t]{2}{*}{$\begin{array}{l}\text { Participants } \\
\text { (studies), } n\end{array}$} & \multirow[t]{2}{*}{$\begin{array}{l}\text { Risk of } \\
\text { bias }\end{array}$} & \multirow[t]{2}{*}{ Inconsistency } & \multirow[t]{2}{*}{ Indirection } & \multirow[t]{2}{*}{ Imprecision } & \multirow[t]{2}{*}{$\begin{array}{l}\text { Publication } \\
\text { bias }\end{array}$} & \multirow{2}{*}{$\begin{array}{l}\text { Quality of } \\
\text { the evidence } \\
\text { (GRADE) }\end{array}$} \\
\hline & $\begin{array}{l}\text { Risk with } \\
\text { COT }\end{array}$ & $\begin{array}{l}\text { Risk with } \\
\text { HFNC }\end{array}$ & & & & & & & & \\
\hline Intubation rate & $\begin{array}{l}102 / 907 \\
(11.2 \%)\end{array}$ & $\begin{array}{l}67 / 947 \\
(7.0 \%)\end{array}$ & $\begin{array}{l}0.52 \\
(0.34,0.79)\end{array}$ & $\begin{array}{l}1854 \\
\text { (8 RCTs) }\end{array}$ & Serious $^{\mathrm{a}}$ & Not serious & $\begin{array}{l}\text { Not } \\
\text { serious }\end{array}$ & Not serious & Undetected & $\begin{array}{l}\oplus \oplus \oplus \circ \\
\text { Moderate }\end{array}$ \\
\hline $\begin{array}{l}\text { Mechanical } \\
\text { ventilation rate }\end{array}$ & $\begin{array}{l}145 / 937 \\
(15.5 \%)\end{array}$ & $\begin{array}{l}98 / 977 \\
(10.0 \%)\end{array}$ & $\begin{array}{l}0.56 \\
(0.33,0.97)\end{array}$ & $\begin{array}{l}1914 \\
\text { (9 RCTs) }\end{array}$ & Serious $^{\mathrm{a}}$ & Serious $^{b}$ & $\begin{array}{l}\text { Not } \\
\text { serious }\end{array}$ & Not serious & Undetected & $\oplus \oplus \circ \circ$ Low \\
\hline Escalation rate & $\begin{array}{l}167 / 937 \\
(17.8 \%)\end{array}$ & $\begin{array}{l}98 / 977 \\
(10.0 \%)\end{array}$ & $\begin{array}{l}0.45 \\
(0.31,0.67)\end{array}$ & $\begin{array}{l}1914 \\
\text { (9 RCTs) }\end{array}$ & Serious $^{\mathrm{a}}$ & Not serious & $\begin{array}{l}\text { Not } \\
\text { serious }\end{array}$ & Not serious & Undetected & $\begin{array}{l}\oplus \oplus \oplus \circ \\
\text { Moderate }\end{array}$ \\
\hline Mortality & $\begin{array}{l}51 / 732 \\
(6.8 \%)\end{array}$ & $\begin{array}{l}57 / 765 \\
(7.4 \%)\end{array}$ & $\begin{array}{l}1.01 \\
(0.67,1.53)\end{array}$ & $\begin{array}{l}1497 \\
(5 \mathrm{RCTs})\end{array}$ & Serious $^{\mathrm{a}}$ & Not serious & $\begin{array}{l}\text { Not } \\
\text { serious }\end{array}$ & Serious ${ }^{c}$ & Undetected & $\oplus \oplus \circ \circ$ Low \\
\hline
\end{tabular}

COT conventional oxygen therapy, NIV noninvasive mechanical ventilation, HNFC high-flow nasal cannula oxygen, OR odds ratio, RCT randomized controlled trial anblinded intervention

b $2,60 \%$

'Wide $\mathrm{Cl}$ 
Table 3 Quality of evidence of studies that compared HFNC to NIV that were included in the meta-analysis, according to Grades of Recommendation, Assessment, Development and Evaluation (GRADE)

\begin{tabular}{|c|c|c|c|c|c|c|c|c|c|c|}
\hline \multirow[t]{2}{*}{ Outcomes } & \multicolumn{2}{|c|}{$\begin{array}{l}\text { Anticipated absolute } \\
\text { effects }(95 \% \mathrm{Cl})\end{array}$} & \multirow{2}{*}{$\begin{array}{l}\text { Relative } \\
\text { effect OR, } \\
(95 \% \mathrm{Cl})\end{array}$} & \multirow[t]{2}{*}{$\begin{array}{l}\text { Participants } \\
\text { (studies), } n\end{array}$} & \multirow[t]{2}{*}{$\begin{array}{l}\text { Risk of } \\
\text { bias }\end{array}$} & \multirow[t]{2}{*}{ Inconsistency } & \multirow[t]{2}{*}{ Indirection } & \multirow[t]{2}{*}{ Imprecision } & \multirow[t]{2}{*}{$\begin{array}{l}\text { Publication } \\
\text { bias }\end{array}$} & \multirow{2}{*}{$\begin{array}{l}\text { Quality of } \\
\text { the evidence } \\
\text { (GRADE) }\end{array}$} \\
\hline & Risk with NIV & $\begin{array}{l}\text { Risk with } \\
\text { HFNC }\end{array}$ & & & & & & & & \\
\hline $\begin{array}{l}\text { Intubation } \\
\text { rate }\end{array}$ & $\begin{array}{l}172 / 841 \\
(20.5 \%)\end{array}$ & $\begin{array}{l}164 / 810 \\
(20.9 \%)\end{array}$ & $\begin{array}{l}0.96(0.66, \\
1.39)\end{array}$ & $\begin{array}{l}1651 \\
\text { (3 RCTs) }\end{array}$ & Serious $^{\mathrm{a}}$ & Serious $^{\mathrm{bl}}$ & $\begin{array}{l}\text { Not } \\
\text { serious }\end{array}$ & Serious $^{c}$ & Undetected & $\begin{array}{l}\oplus \circ 00 \text { Very } \\
\text { low }\end{array}$ \\
\hline $\begin{array}{l}\text { Escalation } \\
\text { rate }\end{array}$ & $\begin{array}{l}206 / 841 \\
(24.5 \%)\end{array}$ & $\begin{array}{l}198 / 810 \\
(24.4 \%)\end{array}$ & $\begin{array}{l}1.00(0.77 \\
1.28)\end{array}$ & $\begin{array}{l}1651 \\
\text { (3 RCTs) }\end{array}$ & Serious $^{\mathrm{a}}$ & Not serious & $\begin{array}{l}\text { Not } \\
\text { serious }\end{array}$ & Serious ${ }^{c}$ & Undetected & $\oplus \oplus \circ \circ$ Low \\
\hline Mortality & $\begin{array}{l}68 / 841 \\
(8.1 \%)\end{array}$ & $\begin{array}{l}59 / 810 \\
(7.3 \%)\end{array}$ & $\begin{array}{l}0.85(0.43, \\
1.68)\end{array}$ & $\begin{array}{l}1651 \\
\text { (3 RCTs) }\end{array}$ & Serious $^{\mathrm{a}}$ & Serious $^{\mathrm{b} 2}$ & $\begin{array}{l}\text { Not } \\
\text { serious }\end{array}$ & Serious ${ }^{c}$ & Undetected & $\begin{array}{l}\text { 円૦०० Very } \\
\text { low }\end{array}$ \\
\hline
\end{tabular}

COT conventional oxygen therapy, NIV noninvasive mechanical ventilation, HNFC high-flow nasal cannula oxygen, OR odds ratio, $R C T$ randomized controlled trial a Unblinded intervention

b1 $l^{2}, 53 \%$

b2 2 , 69\%

${ }^{c}$ Wide $\mathrm{Cl}$

more RCTs (11 RCTs recruiting 3459 patients); Maitra et al. only included 6 RCTs in their meta-analysis and only compared the prognosis of higher respiratory support, while also finding no significant difference between HFNC and standard oxygen therapy or NIV [27]. We included more outcomes for HFNC, including intubation rate, mechanical ventilation rate, the rate of escalation of respiratory support and mortality. Furthermore, we focused on various prognostic indicators of HFNC compared with COT or NIV, to decrease the population heterogeneity and population bias of the sample.

Our meta-analysis found that HFNC also significantly reduced the rate of intubation, mechanical ventilation and the escalation of respiratory support compared to
COT. HFNC is superior to COT due to the delivery of heated humidified oxygen, higher and more predictable gas flow rates and rates of $\mathrm{FiO}_{2}$, a positive pressure effect and improvement in sputum clearance [3, 4]. Nevertheless, HFNC did not reduce mortality when compared to COT, which could be explained by the complex causes of respiratory failure. Frat et al. [18] enrolled patients in the ICU with acute respiratory failure, most of which had community-acquired pneumonia. Jones et al. [20] included patients in the ED with respiratory failure with the main cause indicated as chronic obstructive pulmonary disease (COPD). The other three RCTs included patients with respiratory failure post extubation $[19,21,22]$, and patients in the study of Parke et al. [22]

\begin{tabular}{|c|c|c|c|c|c|c|c|c|c|c|c|}
\hline a & Study or Subqroup & \multicolumn{2}{|c|}{ HFNC } & \multicolumn{2}{|c|}{ COT } & Weiqht & $\begin{array}{l}\text { Odds Ratio } \\
\text { M-H. Random. } 95 \% \mathrm{Cl}\end{array}$ & \multicolumn{4}{|c|}{$\begin{array}{c}\text { Odds Ratio } \\
\text { M-H, Random, } 95 \% \mathrm{Cl}\end{array}$} \\
\hline & Bell, N.2015 & 0 & 48 & 1 & 52 & $1.7 \%$ & $0.35[0.01,8.90]$ & & & & \\
\hline & Corley, A.2015 & 0 & 81 & 2 & 74 & $1.9 \%$ & $0.18[0.01,3.77]$ & & & & \\
\hline & Frat, J. P.2015 & 40 & 106 & 44 & 96 & $38.4 \%$ & $0.72[0.41,1.26]$ & & & & \\
\hline & Hernandez, G.2016 & 13 & 264 & 32 & 263 & $29.8 \%$ & $0.37[0.19,0.73]$ & & & & \\
\hline & Jones, P. G.2015 & 1 & 172 & 3 & 150 & $3.3 \%$ & $0.29[0.03,2.78]$ & & & & \\
\hline & Lemiale, V.2015 & 5 & 53 & 4 & 49 & $8.6 \%$ & $1.17[0.30,4.64]$ & & & & \\
\hline & Maggiore, S. M.2014 & 6 & 53 & 16 & 52 & $14.5 \%$ & $0.29[0.10,0.81]$ & & & & \\
\hline & Parke, R.2013 & 2 & 170 & 0 & 171 & $1.9 \%$ & $5.09[0.24,106.79]$ & & & & \\
\hline & Total $(95 \% \mathrm{Cl})$ & & 947 & & 907 & $100.0 \%$ & $0.52[0.34,0.79]$ & & & & \\
\hline & Total events & 67 & & 102 & & & & & & & \\
\hline & $\begin{array}{l}\text { Heterogeneity: Tau² = } \\
\text { Test for overall effect: }\end{array}$ & $\begin{array}{l}0.04 ; \mathrm{Chi}^{2} \\
z=3.04(\mathrm{~F}\end{array}$ & $\begin{array}{l}=7.73 \\
P=0.00\end{array}$ & $\begin{array}{l}\mathrm{df}=?(\mathrm{P} \\
02)\end{array}$ & $=0.36$ & 6); $P^{2}=9 \%$ & & 0.01 & ${ }^{0.1}{ }^{1}$ & $\begin{array}{c}10 \\
\text { Favours [COT] }\end{array}$ & $100^{\circ}$ \\
\hline & & HFNC & & NIV & & & Odds Ratio & & Odds $\mathrm{F}$ & Ratio & \\
\hline D & Study or Subqroup & Events & Total & Events & Total & Weiqht & M-H, Random, $95 \% \mathrm{Cl}$ & & M-H, Rando & $\mathrm{m}, 95 \% \mathrm{Cl}$ & \\
\hline & Frat, J. P.2015 & 40 & 106 & 55 & 111 & $26.7 \%$ & $0.62[0.36,1.06]$ & & & & \\
\hline & Hernander, G.2016 & 66 & 290 & 60 & 314 & $36.7 \%$ & $1.25[0.84,1.85]$ & & & & \\
\hline & Stéphan, F.2015 & 58 & 414 & 57 & 416 & $36.6 \%$ & $1.03[0.69,1.52]$ & & & & \\
\hline & Total $(95 \% \mathrm{Cl})$ & & 810 & & 841 & $100.0 \%$ & $0.96[0.66,1.39]$ & & & & \\
\hline & Total events & 164 & & 172 & & & & & & & \\
\hline & $\begin{array}{l}\text { Heterogeneity: Tau }= \\
\text { Test for overall effect: }\end{array}$ & $\begin{array}{l}0.06 ; \text { Chi }^{-} \\
z=0.20\end{array}$ & $\begin{array}{l}=4.29 \\
P=0.8\end{array}$ & $\begin{array}{l}\text { a) } \\
\text { 4f }=2(F\end{array}$ & $P=0.12$ & $2) ; 1^{2}=539$ & & 0.01 & $\begin{array}{c}0.1 \\
\text { Favours [HFNC] }\end{array}$ & $\begin{array}{r}10 \\
\text { Favours [NIV] }\end{array}$ & $100^{\circ}$ \\
\hline
\end{tabular}




\begin{tabular}{|c|c|c|c|c|c|c|c|c|c|c|c|}
\hline \multirow[t]{13}{*}{ a } & Study or Subqroup & $\begin{array}{l}\text { HFNC } \\
\text { Events } \\
\end{array}$ & Total & $\begin{array}{l}\text { COT } \\
\text { Events }\end{array}$ & Total & Weight & $\begin{array}{l}\text { Odds Ratio } \\
\text { M-H. Random, } 95 \% \mathrm{Cl}\end{array}$ & & $\begin{array}{r}\text { Odds } \\
\text { M-H, Rando }\end{array}$ & $\begin{array}{l}\text { Ratio } \\
\text { om, } 95 \% \mathrm{Cl}\end{array}$ & \\
\hline & Bell, N.2015 & 2 & 48 & 3 & 52 & $6.1 \%$ & $0.71[0.11,4.44]$ & & & & \\
\hline & Corley, A.2015 & 3 & 81 & 4 & 74 & $7.8 \%$ & $0.67[0.15,3.11]$ & & & & \\
\hline & Frat, J.P.2015 & 45 & 106 & 51 & 96 & $16.9 \%$ & $0.65[0.37,1.13]$ & & & & \\
\hline & Hernandez, G.2016 & 13 & 264 & 32 & 263 & $15.6 \%$ & $0.37[0.19,0.73]$ & & & & \\
\hline & Jones, P. G.2015 & 9 & 172 & 16 & 150 & $13.6 \%$ & $0.46[0.20,1.08]$ & & & & \\
\hline & Lemiale, V.2015 & 8 & 53 & 4 & 49 & $9.6 \%$ & $2.00[0.56,7.12]$ & & & $=$ & \\
\hline & Maggiore, S. M.2014 & 4 & 53 & 18 & 52 & $10.5 \%$ & $0.15[0.05,0.50]$ & & & & \\
\hline & Parke, R. L.2011 & 3 & 30 & 12 & 30 & $8.6 \%$ & $0.17[0.04,0.67]$ & & & & \\
\hline & Parke, R.2013 & 11 & 170 & 5 & 171 & $11.3 \%$ & $2.30[0.78,6.76]$ & & & & \\
\hline & Total $(95 \% \mathrm{Cl})$ & & 977 & & 937 & $100.0 \%$ & $0.56[0.33,0.97]$ & & & & \\
\hline & Total events & 98 & & 145 & & & & & & & \\
\hline & $\begin{array}{l}\text { Heterogeneity: } \mathrm{Tau}^{2}= \\
\text { Test for overall effect: }\end{array}$ & $\begin{array}{l}3.37 \mathrm{Chi}^{2}= \\
=2.08(\mathrm{P}\end{array}$ & $\begin{array}{l}=20.00 \\
=0.04\end{array}$ & $\begin{array}{l}0, \mathrm{df}=8(\mathrm{~F} \\
\text { 4) }\end{array}$ & $P=0.0$ & 11); $I^{2}=60$ & & 0.01 & $\begin{array}{c}0.1 \\
\text { Favours HFNC] }\end{array}$ & $\begin{array}{c}10 \\
\text { Favours [COT] }\end{array}$ & 100 \\
\hline \multirow[t]{13}{*}{ b } & Study or Subqroup & $\begin{array}{l}\text { HFNC } \\
\text { Events }\end{array}$ & $c_{\text {Total }}$ & $\begin{array}{l}\text { COT } \\
\text { Events }\end{array}$ & Total & Weight & $\begin{array}{l}\text { Odds Ratio } \\
\text { M-H. Random. } 95 \% \mathrm{Cl}\end{array}$ & & Odds & Ratio & \\
\hline & Bell, N.2015 & 2 & 48 & 10 & 52 & $5.3 \%$ & $0.18[0.04,0.88]$ & & & & \\
\hline & Corley A 2015 & 3 & 81 & 5 & 74 & $5.9 \%$ & $0.53[0.12,2.30]$ & & & & \\
\hline & Frat, J. P.2015 & 45 & 106 & 51 & 96 & $20.7 \%$ & $0.65[0.37,1.13]$ & & & & \\
\hline & Hernandez, G.2016 & 13 & 264 & 32 & 263 & $17.4 \%$ & $0.37[0.19,0.73]$ & & & & \\
\hline & Jones, P. G.2015 & 9 & 172 & 16 & 150 & $13.3 \%$ & $0.46[0.20,1.08]$ & & & & \\
\hline & Lemiale, V.2015 & 8 & 53 & 4 & 49 & $7.5 \%$ & $2.00[0.56,7.12]$ & & & & \\
\hline & Maggiore, S. M.2014 & 4 & 53 & 18 & 52 & $8.5 \%$ & $0.15[0.05,0.50]$ & & & & \\
\hline & Parke, R. L.2011 & 3 & 30 & 8 & 30 & $6.1 \%$ & $0.31[0.07,1.29]$ & & & & \\
\hline & Parke, R.2013 & 11 & 170 & 23 & 171 & $15.3 \%$ & $0.45[0.21,0.94]$ & & & & \\
\hline & Total $(95 \% \mathrm{Cl})$ & & 977 & & 937 & $100.0 \%$ & $0.45[0.31,0.67]$ & & & & \\
\hline & Total events & 98 & & 167 & & & & & & & \\
\hline & $\begin{array}{l}\text { Heterogeneity: } \mathrm{Tau}^{2}= \\
\text { Test for overall effect: }\end{array}$ & $\begin{array}{l}11 ; \mathrm{Chi}^{2}= \\
=3.97(\mathrm{P}\end{array}$ & $\begin{array}{l}=12.05 \\
=<0.00\end{array}$ & $\begin{array}{l}5, \mathrm{df}=8(\mathrm{f} \\
\text { j01) }\end{array}$ & $P=0.1$ & 5); $\left.\right|^{2}=34$ & & 0.01 & $\begin{array}{c}0.1 \\
\text { Favours [HFNC] }\end{array}$ & \begin{tabular}{|cc} 
& 1 \\
Favours [COT]
\end{tabular} & 100 \\
\hline \multirow{10}{*}{ C } & & HFNC & & сот & & & Odds Ratio & & Odds & Ratio & \\
\hline & Studv or Subqroup & Events & Total & Events & Total & Weight & M-H. Random. $95 \% \mathrm{Cl}$ & & M-H, Rando & om, $95 \% \mathrm{Cl}$ & \\
\hline & Frat, J.P.2015 & 12 & 106 & 18 & 96 & $27.6 \%$ & $0.55[0.25,1.22]$ & & $\Rightarrow$ & T & \\
\hline & Hernandez, G.2016 & 3 & 264 & 3 & 263 & $6.7 \%$ & $1.00[0.20,4.98]$ & & & & \\
\hline & Jones, P. G.2015 & 35 & 172 & 24 & 150 & $52.5 \%$ & $1.34[0.76,2.38]$ & & & - & \\
\hline & Maggiore, S. M.2014 & 6 & 53 & 5 & 52 & $11.0 \%$ & $1.20[0.34,4.20]$ & & & & \\
\hline & Parke, R.2013 & 1 & 170 & 1 & 171 & $2.2 \%$ & $1.01[0.06,16.21]$ & & & & \\
\hline & Total $(95 \% \mathrm{Cl})$ & & 765 & & 732 & $100.0 \%$ & $1.01[0.67,1.53]$ & & & & \\
\hline & Total events & 57 & & 51 & & & & & & & \\
\hline & $\begin{array}{l}\text { Heterogeneity: } \mathrm{Tau}^{2}= \\
\text { Test for overall effect: }\end{array}$ & $\begin{array}{l}.00 ; \mathrm{Chi}^{2} \\
=0.05(\mathrm{P}\end{array}$ & $\begin{array}{l}=3.25 \\
=0.96\end{array}$ & b) $d f=4(P$ & $=0.52)$ & $; 1^{2}=0 \%$ & & 0.01 & $\begin{array}{cc}1 & 1 \\
\text { Favours [HFNC] } & 1\end{array}$ & \begin{tabular}{|cc}
1 & 10 \\
Favours [COT]
\end{tabular} & 100 \\
\hline \multicolumn{12}{|c|}{$\begin{array}{l}\text { Fig. } \mathbf{6} \text { Comparison of secondary outcomes in patients who received high-flow nasal cannula oxygen (HFNC) compared to conventional oxygen } \\
\text { therapy (COT). a Effect on the rate of mechanical ventilation. } \mathbf{b} \text { Effect on the rate of escalation of respiratory support. } \mathbf{c} \text { Effect on mortality. } \\
\mathrm{Cl} \text { confidence interval, } \mathrm{M}-\mathrm{H} \text { Mantel-Haenszel }\end{array}$} \\
\hline
\end{tabular}

were included after undergoing cardiac surgery. In addition, in three RCTs [13, 22, 44] COT was allowed to escalate to HFNC, and the subgroup analysis found no significant differences in the intubation rate between the two groups, which suggests early conversion to HFNC after failure of COT. Care should also be taken since some patients could not tolerate HFNC: in the study of Jones [20], 11 of 172 patients did not tolerate HFNC and were placed on COT. Finally, the prolonged use of HFNC could result in delayed intubation and increased mortality [48].

NIV has been proven to improve gas exchange and reduce the need for intubation and mortality in patients with respiratory failure, especially in patients with an exacerbation of COPD and those with acute cardiogenic pulmonary oedema $[49,50]$. Compared with NIV, HFNC has some advantages, such as greater patient comfort, lower costs, increased ease in clearing secretions [34] and a lower incidence of adverse effects that could lead to a poorer outcome [18]. We included three RCTs that showed no difference between HFNC and NIV in terms of intubation rate and mortality, which suggests that HFNC was not inferior to NIV pertaining to the patients' prognoses, at least in patients with hypoxaemic respiratory failure. Of the three RCTs, Frat et al. [18] enrolled patients in the ICU with acute hypoxaemic respiratory failure and excluded chronic respiratory failure and cardiogenic pulmonary oedema. A study by Stephan [47] enrolled hypoxemic patients after cardiothoracic surgery. Hernandez et al. [25] included patients with post-extubation respiratory failure and excluded those with hypercapnia. The exacerbation of COPD and acute cardiogenic pulmonary oedema may require further study. 


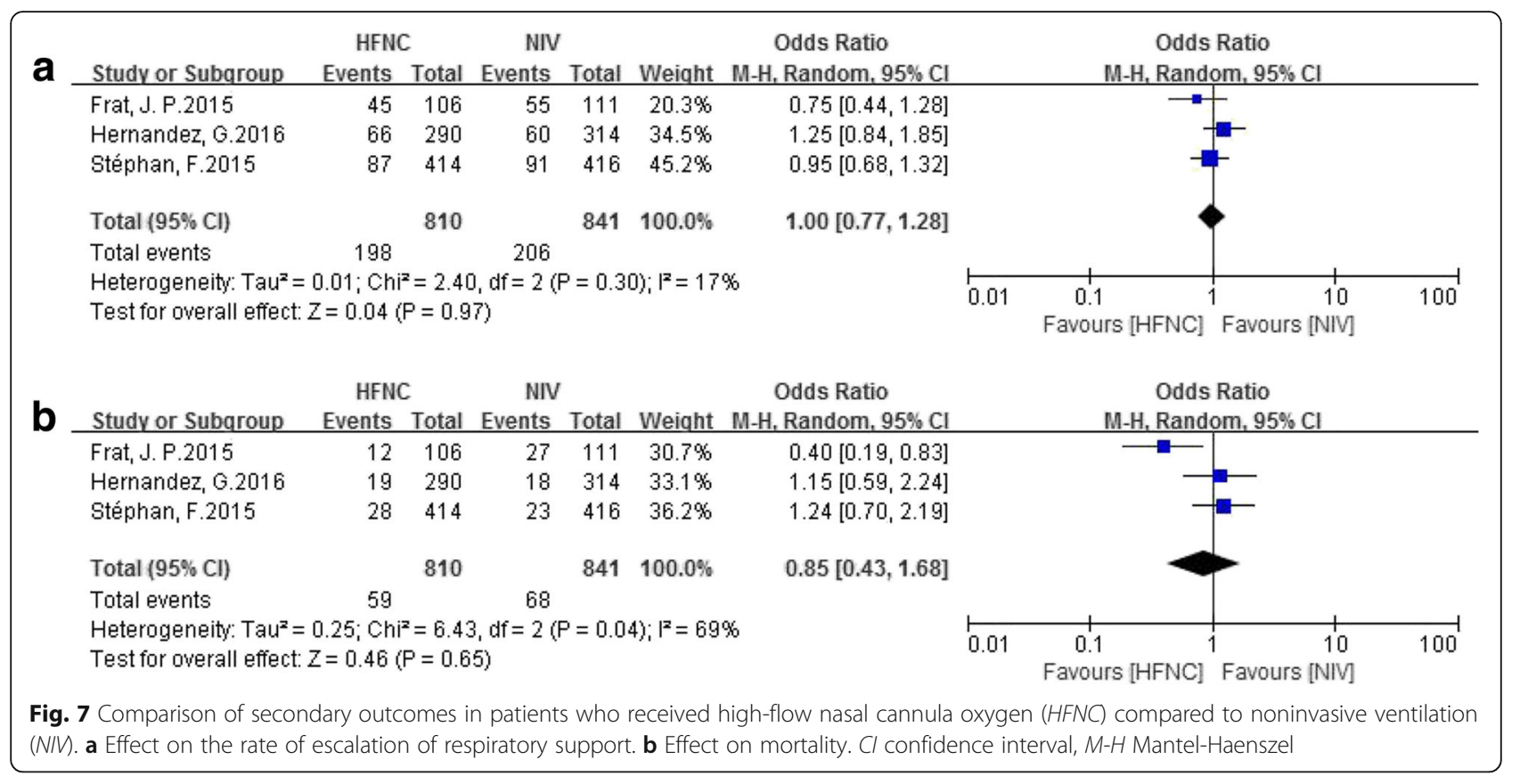

A few RCTs $[19,22,25]$ showed that the length of ICU stay was not influenced by choice. Parke et al. [22] reported no difference in HFNC compared with COT (HFNC $33.4 \mathrm{~h}$ versus COT $28.9 \mathrm{~h}, P=0.08$ [22], and Hernandez et al. [19, 25] reported that the patients' length of stay in the ICU was similar between HFNC and COT (6 days (IQR 2-8) with HFNC versus 6 days (IQR 2-9) with COT, $P=0.29$ ), and between HFNC and NIV (9 days (IQR 4-19) in HFNC versus 10.5 days (IQR $5-19)$ in NIV, $P=0.23$ ). Thus, more RCTs are necessary in the future.

There are several limitations to our meta-analysis. First, the causes of the respiratory distress were heterogeneous in the patients recruited for the studies included. The studies included in the meta-analysis had been performed by researchers who operated independently, and the subjects or interventions in these studies would have differed in ways that could have impacted the results; therefore, we used a random-effects model to make the outcomes conservative and easy to justify. The subgroup analysis showed that HFNC may be more suitable for patients with post-extubation ARF. Second, the duration of treatment and the modes of HFNC and NIV were also variable, which further increased the heterogeneity. Third, all the RCTs included had a high risk of performance bias due to the dramatic differences between HFNC, COT and NIV, which made blinding impossible. Finally, all the studies included in this meta-analysis received sponsorship from Fisher and Paykel Healthcare, although most of the articles $[13,18-20,44-46]$ state that the study design and data analysis were independent of commercial interference.

\section{Conclusions}

In conclusion, compared with COT, HFNC reduced the rate of intubation, mechanical ventilation and escalation of respiratory support. When compared to NIV, HFNC showed similar results. Large-scale randomized controlled trials are necessary to confirm our findings.

\section{Key messages}

- HFNC showed promise in reducing the need for intubation, mechanical ventilation and escalation of respiratory support compared to COT. Large-scale randomized controlled trials are needed to provide more robust evidence.

\section{Additional files}

Additional file 1: Search strategy. (DOCX $16 \mathrm{~kb}$ )

Additional file 2: Table of studies excluded from the meta-analysis. (DOCX 19 kb)

Additional file 3: Table of quality assessment of the included RCTs using the Cochrane Collaboration tool. (DOCX $17 \mathrm{~kb}$ )

Additional file 4: Egger's regression figures for primary or secondary outcomes of HFNC versus COT. a Intubaiton rate. $\mathbf{b}$ Mechanical ventilation rate. c Escalation rate. d Mortality. (PDF 433 kb)

Additional file 5: Table of subgroup analysis of HFNC versus COT. (DOCX $18 \mathrm{~kb}$ )

\section{Abbreviations}

AHRF: Acute hypoxaemic respiratory failure; ARF: Acute respiration failure; BMI: Body mass index; Cl: Confidence interval; COPD: Chronic obstructive pulmonary disease; COT: Conventional oxygen therapy; CTVS: Cardiothoracic and vascular surgery; ED: Emergency department; $\mathrm{FiO}_{2}$ : Fraction of inspired oxygen; FM: Face mask; GRADE: Grading of recommendations assessment, 
development, and evaluation; HFNC: High-flow nasal cannula oxygen; ICU: Intensive care unit; MD: Mean difference; M-H: Mantel-Haenszel; NIV: Non-invasive ventilation; OR: Odd ratio; PD: Pneumology department; PRISMA: Preferred Reporting Items for Systematic Reviews and Meta-Analyses; RCT: Randomized controlled trial; RF: Respiratory failure; SE: Standard error

\section{Acknowledgements}

We would like to thank Jianping Liu (Evidence Based Medicine Center, Beijing University of Chinese Medicine) for his guidance on statistics.

\section{Funding}

No funding was received.

\section{Availability of data and materials}

The authors declare that all data supporting the findings of this study are available within the article and its Additional files.

\section{Authors' contributions}

HYZ conceived of and designed the study, participated in the literature search, collected the data, performed the statistical analysis, interpreted the results and drafted the manuscript. HXW participated in the literature search, collected the data, performed the statistical analysis and helped in drafting the manuscript. FS participated in the literature search and data analysis and revised the manuscript. SL participated in the study design, literature search and coordination. YZA participated in study design and coordination and revised the manuscript. All authors read and approved of the final manuscript for publication.

\section{Ethical approval and consent to participate}

Not applicable.

\section{Consent for publication}

Not applicable.

\section{Competing interests}

The authors declare that they have no competing interests.

\section{Publisher's Note}

Springer Nature remains neutral with regard to jurisdictional claims in published maps and institutional affiliations.

\section{Author details}

'Department of Critical Care Medicine, Peking University People's Hospital, No. 11 Xizhimen South Street, Xicheng District, Beijing 100044, China. ${ }^{2}$ Department of Epidemiology and Biostatistics, School of Public Health, Peking University Health Science Center, Beijing 100038, China.

Received: 20 December 2016 Accepted: 19 June 2017

Published online: 12 July 2017

\section{References}

1. Nishimura M. High-flow nasal cannula oxygen therapy in adults. J Intensive Care. 2015;3:15.

2. Sotello D, Rivas M, Mulkey Z, Nugent K. High-flow nasal cannula oxygen in adult patients: a narrative review. Am J Med Sci. 2015;349:179-85.

3. Spoletini G, Alotaibi M, Blasi F, Hill NS. Heated humidified high-flow nasal oxygen in adults: mechanisms of action and clinical implications. Chest. 2015;148:253-61.

4. Nishimura M. High-flow nasal cannula oxygen therapy in adults: physiological benefits, indication, clinical benefits, and adverse effects. Respir Care. 2016;61:529-41.

5. Hayami H, Mizutani K, Shioda M, Takaki S, Maejima H, et al. Use of high-flow nasal canulae: effect on alveolar pressure and its limitation. Crit Care. 2013;17 Suppl 2:91.

6. Parke R, McGuinness S, Eccleston M. Nasal high-flow therapy delivers low level positive airway pressure. Br J Anaesth. 2009;103:886-90.

7. Dysart K, Miller TL, Wolfson MR, Shaffer TH. Research in high flow therapy: mechanisms of action. Respir Med. 2009;103:1400-5.

8. Wagstaff TA, Soni N. Performance of six types of oxygen delivery devices at varying respiratory rates. Anaesthesia. 2007;62:492-503.
9. Lee JH, Rehder KJ, Williford L, Cheifetz IM, Turner DA. Use of high flow nasal cannula in critically ill infants, children, and adults: a critical review of the literature. Intensive Care Med. 2013;39:247-57.

10. Cuquemelle E, Pham T, Papon JF, Louis B, Danin PE, Brochard L. Heated and humidified high-flow oxygen therapy reduces discomfort during hypoxemic respiratory failure. Respir Care. 2012;57:1571-7.

11. Itagaki T, Okuda N, Tsunano Y, Kohata H, Nakataki E, Onodera M, et al. Effect of high-flow nasal cannula on thoraco-abdominal synchrony in adult critically III patients. Respir Care. 2014;59:70-4.

12. Sztrymf B, Messika J, Bertrand F, Hurel D, Leon R, Dreyfuss D, et al. Beneficial effects of humidified high flow nasal oxygen in critical care patients: a prospective pilot study. Intensive Care Med. 2011;37:1780-6.

13. Bell $N$, Hutchinson CL. Randomised control trial of humidified high flow nasal cannulae versus standard oxygen in the emergency department. Emerg Med Australasia. 2015:27:537-41.

14. Roca O, Riera J, Torres F, Masclans JR. High-flow oxygen therapy in acute respiratory failure. Respir Care. 2010:55:408-13.

15. Rittayamai N, Tscheikuna J, Rujiwit P. High-flow nasal cannula versus conventional oxygen therapy after endotracheal extubation: a randomized crossover physiologic study. Respir Care. 2014;59:485-90.

16. Sztrymf B, Messika J, Mayot T, Lenglet H, Dreyfuss D, Ricard JD. Impact of high-flow nasal cannula oxygen therapy on intensive care unit patients with acute respiratory failure: A prospective observational study. J Crit Care. 2012;27:324. e329-13.

17. Lenglet H, Sztrymf B, Leroy C, Brun P, Dreyfuss D, Ricard JD. Humidified high flow nasal oxygen during respiratory failure in the emergency department: feasibility and efficacy. Respir Care. 2012;57:1873-8.

18. Frat JP, Thille AW, Mercat A, Girault C, Ragot S, Perbet S, et al. High-flow oxygen through nasal cannula in acute hypoxemic respiratory failure. $\mathrm{N}$ Engl J Med. 2015;372:2185-96.

19. Hernandez G, Vaquero C, Gonzalez P, Subira C, Frutos-Vivar F, et al. Effect of postextubation high-flow nasal cannula vs conventional oxygen therapy on reintubation in low-risk patients: a randomized clinical trial. JAMA. 2016:315:1354-61.

20. Jones PG, Kamona S, Doran O, Sawtell F, Wilsher M. Randomized controlled trial of humidified high-flow nasal oxygen for acute respiratory distress in the emergency department: the HOT-ER study. Respir Care. 2016;61:291-9.

21. Maggiore SM, Idone FA, Vaschetto R, Festa R, Cataldo A, Antonicelli F, et al. Nasal high-flow versus Venturi mask oxygen therapy after extubation. Effects on oxygenation, comfort, and clinical outcome. Am J Respir Crit Care Med. 2014;190:282-8.

22. Parke R, McGuinness S, Dixon R, Jull A. Open-label, phase II study of routine high-flow nasal oxygen therapy in cardiac surgical patients. Br J Anaesth. 2013;111:925-31.

23. Carron M, Freo U, BaHammam AS, Dellweg D, Guarracino F, Cosentini R, et al. Complications of non-invasive ventilation techniques: a comprehensive qualitative review of randomized trials. Br J Anaesth. 2013;110:896-914.

24. Sferrazza Papa GF, Di Marco F, Akoumianaki E, Brochard L. Recent advances in interfaces for non-invasive ventilation: from bench studies to practical issues. Minerva Anestesiol. 2012;78:1146-53.

25. Hernandez G, Vaquero C, Colinas L, Cuena R, Gonzalez P, Canabal A, et al. Effect of postextubation high-flow nasal cannula vs noninvasive ventilation on reintubation and postextubation respiratory failure in high-risk patients: a randomized clinical trial. JAMA. 2016:316:1565-74.

26. Monro-Somerville T, Sim M, Ruddy J, Vilas M, Gillies MA. The effect of high-flow nasal cannula oxygen therapy on mortality and intubation rate in acute respiratory failure: a systematic review and meta-analysis. Crit Care Med. 2016;45:e449-56

27. Maitra S, Som A, Bhattacharjee S, Arora MK, Baidya DK. Comparison of high-flow nasal oxygen therapy with conventional oxygen therapy and noninvasive ventilation in adult patients with acute hypoxemic respiratory failure: a meta-analysis and systematic review. J Crit Care. 2016;35:138-44.

28. Stewart LA, Clarke M, Rovers M, Riley RD, Simmonds M, Stewart G, et al. Preferred Reporting Items for Systematic Review and Meta-Analyses of individual participant data: the PRISMA-IPD Statement. JAMA. 2015:313:1657-65.

29. Higgins JP, Altman DG, Gotzsche PC, Juni P, Moher D, Oxman AD, et al. The Cochrane Collaboration's tool for assessing risk of bias in randomised trials. BMJ. 2011;343:d5928.

30. Egger M, Davey Smith G, Schneider M, Minder C. Bias in meta-analysis detected by a simple, graphical test. BMJ. 1997;315:629-34. 
31. Guyatt GH, Oxman AD, Kunz R, Falck-Ytter Y, Vist GE, Liberati A, et al. Going from evidence to recommendations. BMJ. 2008;336:1049-51.

32. Higgins JP, Thompson SG, Deeks JJ, Altman DG. Measuring inconsistency in meta-analyses. BMJ. 2003;327:557-60

33. Brotfain E, Zlotnik A, Schwartz A, Frenkel A, Koyfman L, Gruenbaum SE, et al. Comparison of the effectiveness of high flow nasal oxygen cannula versus standard non-rebreather oxygen face mask in post-extubation intensive care unit patients. Isr Med Assoc J. 2014;16:718.

34. Frat JP, Brugiere B, Ragot $S$, Chatellier D, Veinstein A, Goudet V, et al. Sequential application of oxygen therapy via high-flow nasal cannula and noninvasive ventilation in acute respiratory failure: an observational pilot study. Respir Care. 2015;60:170-8.

35. Roca O, de Acilu MG, Caralt B, Sacanell J, Masclans JR, ICU collaborators. Humidified high flow nasal cannula supportive therapy improves outcomes in lung transplant recipients readmitted to the intensive care unit because of acute respiratory failure. Transplantation. 2015;99:1092-8.

36. Tiruvoipati R, Lewis D, Haji K, Botha J. High-flow nasal oxygen vs high-flow face mask: a randomized crossover trial in extubated patients. J Crit Care 2010;25:463-8.

37. Yoo JW, Synn A, Huh JW, Hong SB, Koh Y, Lim CM. Clinical efficacy of highflow nasal cannula compared to noninvasive ventilation in patients with post-extubation respiratory failure. Korean J Intern Med. 2016;31:82-8.

38. Yildirim F. High-flow nasal oxygen vs noninvasive positive airway pressure in hypoxemic patients after cardiothoracic surgery: a randomized clinical trial. [Turkish]. Journal of Medical and Surgical Intensive Care Medicine. 2015;6:60-2.

39. Hui D, Morgado M, Chisholm G, Withers L, Nguyen Q, Finch C, et al. Highflow oxygen and bilevel positive airway pressure for persistent dyspnea in patients with advanced cancer: a phase II randomized trial. J Pain Symptom Manage. 2013;46:463-73.

40. Rittayamai N, Tscheikuna J, Praphruetkit N, Kijpinyochai S. Use of high-flow nasal cannula for acute dyspnea and hypoxemia in the emergency department. Respir Care. 2015;60:1377-82.

41. Schwabbauer N, Berg B, Blumenstock G, Haap M, Hetzel J, Riessen R. Nasal high-flow oxygen therapy in patients with hypoxic respiratory failure: effect on functional and subjective respiratory parameters compared to conventional oxygen therapy and non-invasive ventilation (NIV). BMC Anesthesiol. 2014;14:66.

42. Lucangelo U, Vassallo FG, Marras E, Ferluga M, Beziza E, Comuzzi L, et al. High-flow nasal interface improves oxygenation in patients undergoing bronchoscopy. Crit Care Res Pract. 2012;2012:506382.

43. Simon M, Braune S, Frings D, Wiontzek AK, Klose H, Kluge S. High-flow nasal cannula oxygen versus non-invasive ventilation in patients with acute hypoxaemic respiratory failure undergoing flexible bronchoscopy-a prospective randomised trial. Crit Care. 2014;18:712.

44. Corley A, Bull T, Spooner AJ, Barnett AG, Fraser JF. Direct extubation onto high-flow nasal cannulae post-cardiac surgery versus standard treatment in patients with a $\mathrm{BMI}>/=30$ : a randomised controlled trial. Intensive Care Med. 2015:41:887-94.

45. Lemiale V, Mokart D, Mayaux J, Lambert J, Rabbat A, Demoule A, et al. The effects of a 2-h trial of high-flow oxygen by nasal cannula versus Venturi mask in immunocompromised patients with hypoxemic acute respiratory failure: a multicenter randomized trial. Crit Care. 2015;19:380.

46. Parke RL, McGuinness SP, Eccleston ML. A preliminary randomized controlled trial to assess effectiveness of nasal high-flow oxygen in intensive care patients. Respir Care. 2011;56:265-70.

47. Stephan F, Barrucand B, Petit P, Rézaiguia-Delclaux S, Médard A, Delannoy B, et al. High-flow nasal oxygen vs noninvasive positive airway pressure in hypoxemic patients after cardiothoracic surgery: a randomized clinical trial. JAMA. 2015;313:2331-9.

48. Kang BJ, Koh Y, Lim CM, Huh JW, Baek S, Han M, et al. Failure of high-flow nasal cannula therapy may delay intubation and increase mortality. Intensive Care Med. 2015;41:623-32.

49. Lindenauer PK, Stefan MS, Shieh MS, Pekow PS, Rothberg MB, Hill NS. Outcomes associated with invasive and noninvasive ventilation among patients hospitalized with exacerbations of chronic obstructive pulmonary disease. JAMA Intern Med. 2014;174:1982-93.

50. Masip J, Roque M, Sanchez B, Fernandez R, Subirana M, Exposito JA. Noninvasive ventilation in acute cardiogenic pulmonary edema: systematic review and meta-analysis. JAMA. 2005;294:3124-30.

\section{Submit your next manuscript to BioMed Central and we will help you at every step:}

- We accept pre-submission inquiries

- Our selector tool helps you to find the most relevant journal

- We provide round the clock customer support

- Convenient online submission

- Thorough peer review

- Inclusion in PubMed and all major indexing services

- Maximum visibility for your research

Submit your manuscript at www.biomedcentral.com/submit

) Biomed Central 